\title{
SOME REMARKS ON THE NEW AMENDMENTS TO THE PROCEDURE OF THE ADOPTION'S INSTITUTION
}

\author{
L. Cetean-Voiculescu
}

\section{Laura Cetean-Voiculescu}

Legal and Administrative Sciences Department, Faculty of Law and Social Sciences, "1 Decembrie 1918" University from Alba Iulia, Alba Iulia, Romania *Correspondence: Laura Cetean-Voiculescu, Lecturer PhD, “1 Decembrie 1918” University from Alba Iulia, 5 Gabriel Bethlen St., Alba Iulia, Romania E-mail: lauravoiculescu@yahoo.com

\begin{abstract}
Adoption is one of the most important measures to protect children in need, namely that category of children who are deprived of parental care, loss due to various reasons. If a child in need cannot be maintained or reinstated in his natural family, state authorities must have an alternative measure of protection: guardianship, special protective measures provided by Law no. 272/2004 on the protection and promotion of children's rights (placement, emergency placement or specialized supervision) or adoption, regulated by Law no. $273 / 2004$.

This paper aims to critically analyze the Adoption of the new rules, with special regard to the adoption's administrative and judicial proceedings.
\end{abstract}

Keywords: Adoption procedure, individualized plan of protection, substantive conditions for adoption, celerity, child's best interests, the principle of continuity.

\section{Introduction}

If a child in need cannot be maintained or reinstated in his natural family, state authorities must have an alternative measure of protection: guardianship, special protective measures provided by Act no. 272/2004 on the protection and promotion of children's rights (placement, emergency placement or specialized supervision) or adoption, regulated by Act no. $273 / 2004$.

If the individualized protection plan reveals that the best measure of protection for a child in need is adoption, it carries out an extensive procedure, which runs in parallel on two areas: administrative and judicial.

The Act governing adoption's procedure no. 273/2004 was amended successively by a series of laws, the latter being of recent date, and the purpose of this article is a critical analysis of the latter changes in matter.

\section{Current regulatory}

This year, the Law on the legal status of adoption was republished ${ }^{1}$ in the Official Gazette of Romania no. 259/19 April 2012, subsequently appearing H.G. 350/2012 approving the Methodological Norms for applying Law no. 273/2004. This is the second reprint of mentioned Act after that on the Official Gazette no. 788/2009, as amended by Law no. 71/2011 for the implementation of the new Civil Code.

\footnotetext{
${ }^{1}$ Under the provisions of art. X of Law. 233/2011 amending and supplementing Law no. 273/2004, published in Official Gazette of Romania no. 880/7 December 2011 and entered into force on 7 April 2012.
} 
Regarding republication believe that it was imperative given that the new Civil Code governing this child protection measure, as noted on another occasion ${ }^{2}$, the regulations contained in two acts were not entirely compatible.

But given that new rules and legal norms are found some critics consider appropriate a succinct analysis of these changes in relation to the regulation of adoption procedures contained in the Civil Code.

Thus, the changes in adoption proceedings are in force, by republication of the Law no. 273/2004, starting with April 7, 2012.

\section{General and special law in adoption procedure}

If prior to the abrogation of the Family Code, which represent the general law regarding all legal relationships which form the subject of family law, general law presently role in this regard is played by the new Civil Code, which in Book II entitled "On the Family" includes a set of rules generally applicable legally binding marriage relationship, parentage, adoption and other similar reports of family law.

On Adoption, Civil Code includes in Title III (relationship) a separate chapter (Chapter III) a set of legal rules governing the adoption, rules with a general character. Special character rules are found in Law no. 273/2004 on the legal status of adoption, which is intended to be the law governing the particular aspects of the actual procedure of adoption, both the administrative and the judicial.

On internal adoption procedure, the stage of obtaining the certificate of a person or family able to adopt (administrative procedure)

The first step of this phase is the requirement of the adopter or the adopting family to issue the certificate of a person or family able to adopt, formulated by the General Directorate of Social Assistance and Child Protection at their home.

Following this request, the Department conducted an assessment of parenting skills, the analysis of performance guarantees moral and material conditions, and preparation for assuming the role of parent.

Within 120 days from the date of application for final evaluation shall report on the ability of the applicant to adopt, and this report will contained the proposal to release the certificate or not.

The evaluation result can be favorable, in which case the certificate will be issued per person or family able to adopt, or negative, issued by order of granting the certificate, in which case the person or family have the possibility of submitting an appeal.

There are cases where it is not necessary to obtain the certificate:

- The adoption of the person, who has acquired full legal capacity,

- The adoption of the child by the natural or adoptive parent's spouse.

If the above mentioned change law called this stage, the adopter or the adopting family certificate, the name was changed in step evaluation adopter or adoptive family to obtain the certificate.

Also, if the previous law refers only to assess collateral moral and material conditions, this law is more explicit, defining even as that process evaluation like that process which identifies parenting skills, assess performance guarantees moral and material conditions of adopter or adoptive family and preparing to assume, knowingly, the role of parent.

Another new legislation is the final evaluation report, a document shall be made compulsory up to 120 days (not 60 days as it was earlier) from the date of submission of the evaluation, including evaluation results and the proposal on the issuance or failure to issue the certificate.

\footnotetext{
${ }^{2}$ Laura Cetean-Voiculescu, Ada Hurbean, Considerations regarding the amendments to legislation on child protection through the new civil code, in Challenges of the Knowledge Society, Pro Universitaria Publishing House, Bucharest, 2012.
} 
Also a new legislative adoption procedure is the possibility of withdrawing the certificate on the grounds expressly provided by law, and termination of validity of the certificate.

An appeal against the decision is no longer the revaluation under current regulations, but appeal, which is solved by the Romanian Office for Adoptions, and not by the court. In addition objection was preserved and the provision for appeal against refusal or withdrawal of the certificate.

\section{On internal adoption procedure, initiation stage (Judicial Procedure)}

Domestic adoption can be achieved more easily after the change of the law on adoption procedure. Thus, if the previous law provided that the previous requirement adoption making efforts to reintegrate child in the family or extended family placement or foster child, now must pass within 1 year of the establishment of special protection measure natural parents or relatives up to the fourth degree cannot be found or not working in family reintegration or say they do not want to deal with growth or childcare. Do not wait any longer fulfilling this period if the child was registered as born of unknown parents, where adoption can be ordered within 30 days from the issuance date of birth of the child.

\section{On the fit between the child and the person / family able to adopt (administrative procedure)}

The phase of the matching between the child and the adopting person or family is introduced into law on internal adoption procedure. As defined by law even in $36^{\text {th }}$ article is a preliminary stage custody for adoption, a stage in which it identifies and selects the most appropriate person/family certified as fit to adopt that child needs and establish compatibility between the child and the person/adoptive family.

Matching will be done with priority between the child and the extended family relatives or between it and other people with whom the child has enjoyed family life for a minimum of 6 months.

Matching can be:

- Theoretical, conducted by the Office for children in its records and to be entrusted for adoption by identifying and selecting from the National Registry for adoption of certified persons.

- Practice, when selecting the most appropriate people conducted by department of adoptions and the post-adoptions structure direction.

At the end of this stage, prepare a document called matching report, which will include conclusions on finding compatibility between the child and the adopting person, together with a proposal for initiating court next step.

\section{With regard to custody for adoption (legal proceedings)}

The main change on this stage is the removal of a period of 30 days from the date of the final and irrevocable decision authorizing domestic adoption must identify the most appropriate person to custody of the child or family.

Even if this change is likely to affect the principle of celerity which must govern this procedure, on the other hand the current law formula is a step in this direction, providing that decisions which the custody process applications for adoption are enforceable the date of delivery.

\section{On the approval of adoption (legal proceedings)}

A declaration of adoption must be accompanied by a series of acts, from those in the old regulation modifying the law added three, namely:

- Report of the natural parents' advice and information for child adoption by the natural father husband;

- The document recording the expertise results to confirm parentage to the father, accomplished by anthropometric expertise in child adoption by the wife if natural parent when the child has been recognized administratively by his father and if the child' paternity 
was established by court noted that its recognition by the father, which confirms the parties' bargain, without having examined the merits of the application;

- Notarized statement on oath.

Also, at this stage has changed, and rightly an article that regulate post-adoption, because the new regulation provides a separate chapter - Chapter IX, which deals exclusively with monitoring and post-adoption activities.

The procedure of international adoption ${ }^{3}$

Fortunately, as I have said on other occasions ${ }^{4}$, the regulation on international adoptions has changed as well.

The most important change is related to the category of people who can adopt. Before, if the adopter or the adopting family living abroad should be relative to grade III with the child, according to current rules international adoption can occur in the following situations:

- Adopter or adoptive family one spouse is relative to grade IV including child which was affirmed domestic adoption procedures;

- Adopter or adoptive family one spouse is a Romanian citizen, but only for children who upheld opening internal adoption procedure could not be identified adoptive or adoptive family normally resident in Romania.

- Adopter is the spouse of a natural parent of the child whose adoption is required.

Other novelties are some additional procedural rules for international adoption in the match; this is accomplished by the Office, in compliance with the methodology developed by him and approved by Government Decision. Selected person must actually reside in the country for at least 30 consecutive days in the home will report on the match that will send Office. In turn, shall notify the competent central authorities of the receiving State or approved organizations selecting adopter.

Finally, Final items that sanctions were repealed, for the same reasons of the existence of a separate chapter, introduced by the new amendment, on monitoring and post-adoption activities.

\section{Conclusions and proposals}

We cannot express our gratitude that this time, the legislature took into account the amendments to the law on adoption procedure, the recommendations doctrine in this area, although there are aspects for improvement in adoption proceedings. following:

In light of revealing in this paper and other items that were not identified, the

1. Agreement required the implementation of the provisions of the Civil Code and the Act relating to adoption proceedings.

2. It is necessary to establish regulatory domain of each of the two acts. For example, the $453^{\text {rd }}$ article and $454^{\text {th }}$ article from Civil Code contains legal provisions referring to the special law so that it is clear that international adoption and adoption proceedings are governed solely by the Act no. 273/2004 as a special law on Adoption.

3. Correcting grammatical errors and inconsistencies in the wording of the two acts, as the grammatical interpretation of legal norms is very important and with many implications for legal practice.

\footnotetext{
${ }^{3}$ For more details see Laura Cetean-Voiculescu, Dreptul familiei, Hamangiu Publishing House, Bucharest, 2012, pp. 303-306.

${ }^{4}$ A. Drăgoi, Laura Cetean-Voiculescu, Curs teoretic şi aplicativ de dreptul familiei, Agora University Press, Oradea, 2007, pp. 196-197.
} 


\section{Bibliography}

Laura Cetean-Voiculescu, Ada Hurbean, Considerations regarding the Amendments to Legislation on child protection through the new civil code, in Challenges of the Knowledge Society, Pro Universitaria Publishing House, Bucharest, 2012;

Laura Cetean-Voiculescu, Dreptul familiei, "Hamangiu" Publishing House, Bucharest, 2012;

F. Emese, Dreptul familiei, “CH Beck” Publishng Huse, Bucharest, 2011;

The new Civil Code, Law no. 287/2009;

Laura Cetean-Voiculescu, Drept în asistență socială, "Risoprint" Publishing House, Cluj-Napoca, 2008;

A. Drăgoi, Laura Cetean-Voiculescu, Curs teoretic şi aplicativ de dreptul familiei, Agora University Press, Oradea, 2007;

Law no. 273/2004 regarding the adoption procedure. 